\title{
Investigation of Fatigue Damage Process Based on Dissipated Energy Measurement
}

\author{
学 ○赤井 淳嗣（神户大） \\ 正塩澤 大輝 (神戸大) \\ 正阪上 隆英（神戸大）
}

Atsushi AKAI, Kobe University, 1-1, Rokkoudaichou, Nada-ku, Kobe

Takahide SAKAGAMI, Kobe University

Daiki SHIOZAWA, Kobe University

\section{1 緒 言}

近年, 赤外線カメラを用いた散逸エネルギ計測による疲労 限度予測法が注目されている。この手法は, 疲労限度および 疲労破壊箇所を簡易的に推定できる事から春用化が進んでい る. しかしながら, 散逸エネルギ計測により疲労限度を予測 できる明確な根拠が末だ不明であるため, 散冕エネルギ発生 と疲労損傷との関係を明らかにする必要がある.

本報では，SUS304 鋼の疲労試験中での散逸エネルギ，ひ ずみ変動及びマルテンサイト相の測定を行い, 散逸エネルギ と疲労損傷過程での微視組織変化との関係について検討した.

\section{2 試験方法}

SUS304 鋼試験片に対して, 室温大気中において軸力疲労 試験を行った. 負荷条件としては, 応力比 $R=-1$, 繰返し周波 数 $f=5 \mathrm{~Hz}$, 応力波形は正弦波とした. 規定の繰返し数に達す る度に，散逸エネルギ，及びマルテンサイト相の測定を行っ た. 散逸エネルギ測定には, 赤外線カメラ(Cedip 製 Taitanium) を, 散逸エネルギ処理には画像処理ソフトAltair LI を用いた. マルテンサイト相の測定には，フェライトスコープ (Fisher Inc.製）を用いた。 また，試験片中央に貼付したひずみゲー ジにより疲労試験中のひずみ変動を測定した.

\section{3 実䀦結果および考察}

一定応力振幅 $\sigma_{a}=210 \mathrm{MPa}$ で疲労試験をした場合の実験結 果について述べる.この疲労試験では $N=2.0 \times 10^{6}$ cycles 時で 試験片は破断しなかった。

試験片中央部で得られた散逸エネルギの平均值の変化を Fig. 1 に示す.Fig. 1 より, 疲労試験初期では繰返し数と共に, 散逸エネルギは増加し, 約 2 万回で急激に減少した後, 一定 值を示していることが分かる. 更に, 約 10 万回で散逸エネル ギは急激に増加した後, 繰返し数と共に減少した.この様に, 散逸エネルギ変化の特徴は Stage I 〜 IIIの 3 つに分けられた.

次に, 塑性ひずみエネルギ変化を Fig. 2 に示す. Fig. 2 より, 塑性ひずみエネルギは, 試験開始から繰返し数と共に增加し, 約 10 万回を境に減少していることが分かる. 塑性ひずみエネ ルギは繰返し負荷過程で不可逆的に放出されるエネルギであ り，この一部分が熱的な散逸エネルギとして放出される.こ のため, 散逸エネルギの Stage I， IIIでの変化は塑性ひずみエ ネルギの変化と良く一致しているものと考えられる. 一方, Stage II では両者の変化は対応していない.この原因について 以下に考察を加える.

SUS304 鋼では疲労損傷過程において加工誘起マルテンサ イト変態が生じ微視的構造が変化する. そこでマルテンサイ 卜相の変化に着目し，マルテンサイト体積率 $\zeta$ の変化を測定 した結果を Fig. 3 に示す. Fig. 3 では, 負荷 1 サイクルに生成 されるマルテンサイト相として増加率 $\mathrm{d} \zeta / \mathrm{d} N$ を算出し合わせ
て表記した. Fig. 3 より, マルテンサイト相は繰返し数とと もに增加しており，特に Stage IIにおいてその増加率は最大 值を示し,その後 StageIII では繰返し数とともに減少している ことが分かる.よって Stage II での散逸エネルギの減少は, 塑 性ひずみエネルギが加工誘起マルテンサイト変態に費やされ たためだと考えられる.

繰返し軟化，硬化は転位の増加，飽和によるものと考えら れるため, 散逸エネルギは転位や相変態などの微視組織構造 の変化を反映したものであることが明らかとなった．散逸エ ネルギは疲労損傷の評価に有効なパラメータであるとともに， 疲労損傷過程に応じて変化することから従来の疲労限度の簡 易推定法の適用には注意が必要であると考えられる.

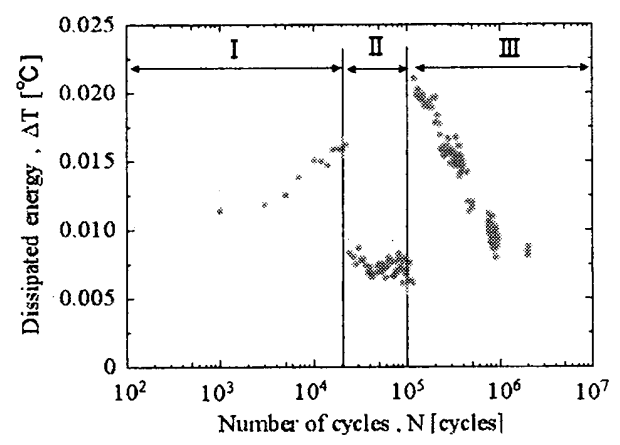

Fig. 1 Result of dissipated energy measured by thermography

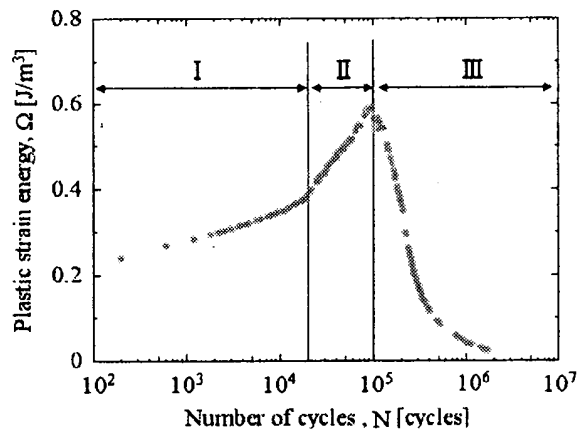

Fig. 2 Change of plastic strain energy

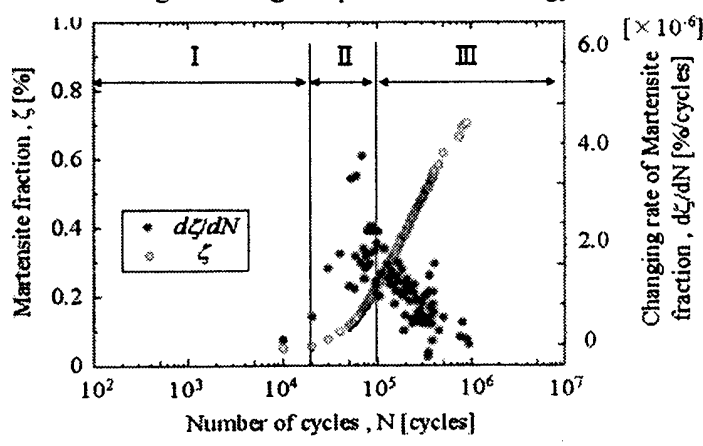

Fig. 3 Martensite fraction measured by FERRITE SCOPE 